\title{
Penerapan Teori Belajar Behavioristik dalam Pembelajaran Pendidikan Agama Islam di Sekolah Menengah Atas
}

\author{
Mohammad Raihan \\ Jurusan Ilmu Agama Islam, Fakultas Ilmu Sosial, Universitas Negeri Padang, Indonesia \\ raihanalghofiqi@gmail.com
}

\begin{abstract}
The theory of behavioristic learning is a learning theory that focuses on a student's changing behavior because of stimulus and response. So it is said that the student learns when it exhibits changes in his behavior. The purpose of this study is to understand and know the importance of applying behavioristic theories to pai study, the study of the PAI covers the range as follows the Qur'an and Hadits, aqidah, equality, ethics, and era. The research methods used are descriptive and qualitative. Through this study, authors attempt to communicate for the methods used by the PAI teacher at SMAN 3 Batam and the changing behavior of the student to apply behavioristic learning theories. Research has found that it forms theories for learning behavioristic in the study of PAI by way of motivation, training, and strengthening student's character. As for the change in good behavior of learns is tolerance, interactive in learning, motivated in learning, reward and punishment.
\end{abstract}

Keywords: Behaviourism, changing behavior, applying

\section{Pendahuluan}

Latar belakang dibuatnya penelitian ini adalah di karenakan pendidikan pada masa sekarang yang kurang menanamkan karakter siswa dan moral/etika pada peserta didik, hal ini disebabkan karena perilaku yang tidak terkontrol akibat dari pergaulan dan pengaruh dari lingkungan sekitarnya. Kurangnya pendidikan seperti ini adalah hal yang sangat memprihatinkan yang membutuhkan perhatian dari kita semua rakyat Indonesia terutama penanggung jawab pendidikan. Karena etika dan moral merupakan hal yang sangat penting dalam dunia pendidikan, di dalam Islam sendiri diajarkan bahwa sebelum kita menuntut ilmu,k ita harus memperhatikan adab dan etika terlebih dahulu. Pepatah arab pernah mengatakan "ilmu tanpa adab merupakan ilmu yang sia-sia". Maka jurnal ini dibuat untuk mewujudkan pendidikan yang berkarakter terutama pada guru. Guru sebagai tenaga pengajar yang berinteraksi secara langsung dengan peserta didik memiliki peran penting dalam pembelajaran.

Tujuan dari penelitian ini adalah memahami pentingnya pengaplikasian teori belajar behavioristik dalam pembelajaran PAI, serta cara-cara pendekatan yang dilakukan teori belajar behaviotistik terhadap siswa itu sendiri dalam pembelajaran PAI. Manfaat dari penelitian ini adalah mengetahui bahwasanya teori belajar behevioristik sendiri pada prakteknya telah dicontohkan dalam agama islam dan dicontohkan oleh nabi Muhammad. Kita dapat juga mengetahui bahwa pedoman akhlak yang patut kita contoh adalah dalam pembelajaran PAI itu sendiri. 
Hubungannya dengan teori belajar behavioristik yaitu penggunaan teori pembelajaran dengan memperhatikan pengembangan materi dan pemilihan materi serta mendesain pembelajaran dengan benar akan memudahkan peserta didik dalam memahami pelajaran. Kesuksesan suatu pembelajaran tidak dapat dilihat secara tekstual saja,akan tetapi dapat dilihat dari pola tingkah laku peserta didik tersebut.

Salah satu teori di Indonesia yang menekankan persoalan perubahan-perubahan tingkah laku terhadap peserta didik adalah teori behavioristik. Jadi, tidak bisa kita pungkiri bahwasanya teori belajar behavioristik telah banyak digunakan guru mata pelajaran dalam mendidik perilaku siswanya. Adapun terkait dengan perilaku maka tidak terlepas dengan pembelajaran PAI itu sendiri. Seperti yang kita ketahui bersama bahwa PAI merupakan mata pelajaran yang harus ada di sekolah.

\section{Tinjauan Pustaka}

Teori belajar behavioristik merupakan teori yang memfokuskan kepada perubahan tingkah laku peserta didik ke arah yang lebih baik. Keberhasilan perubahan tingkah laku peserta didik dapat dilihat dengan bagaimana metode yang diajarkan oleh guru tersebut kepada siswanya. Sehubungan dengan hal tersebut penulis telah melakukan penelitian di SMA Negeri 3 Batam terkait dengan teori belajar behavioristik pada pembelajaran Pendidikan Agama Islam. Proses pengumpulan data pada penelitian ini terkait dengan pengaplikasian teori belajar behavioristik ,penulis melakukan wawancara langsung dengan Ibu Becek Tang, S.Ag., M.M. selaku guru Pendidikan Agama Islam di SMA Negeri 3 Batam.

\section{Metode Penelitian}

Metode penelitian yang digunakan oleh penulis adalah metode penelitian kualitatif. Metode penelitian kualitatif adalah metode yang berdasarkan pada filsafat positivism, sebagaimana halnya filsafat positivism dilakukan pada penelitian yang sifatnya alamiah. Metode penelitian kualitatif berguna untuk memperoleh data yang mendalam dan mengandung makna dan maksud sesuai dengan yang terjadi di lapangan. Langkah utama dalam penelitian dapat dilihat dari teknik pengumpulan data yang dilakukan. Pengumpulan data yang dilakukan oleh penulis adalah observasi (pengamatan), interview (wawancara), dan dokumentasi.

Penjelasan singkatnya bahwa observasi adalah suatu teknik yang dilakukan dalam penelitian dengan melakukan pengamatan pada objek penelitian. Wawancara adalah teknik penelitian yang dilakukan dengan memberikan pertanyaan kepada narasumber dengan maksud untuk memperoleh informasi sesuai dengan topik penelitian. Dokumentasi adalah suatu teknik pengumpulan data dengan menganalisis dokumen yang terkait dengan topik penelitian baik dokumen tertulis, gambar, maupun elektronik.

\section{Hasil dan Pembahasan}

Hasil dan pembahasan yang akan penulis paparkan adalah penelitian di SMA Negeri 3 Batam terkait dengan teori belajar behavioristik pada pembelajaran Pendidikan Agama Islam. Proses pengumpulan data terkait dengan penerapan teori belajar 
behavioristik ini penulis melakukan observasi di sekolah SMA Negeri 3 Batam, wawancara langsung dengan Ibu Becek Tang, S.Ag., M.M. selaku guru Pendidikan Agama Islam di sekolah tersebut dan di akhir wawancara penulis mendokumentasikan foto bersama ibu Becek Tang. Berikut hasil observasi sekolah di SMA Negeri 3 Batam:

SMA Negeri 3 Batam merupakan sekolah menengah atas yang terletak di Jl.Hang Nadim No.3 Kelurahan Belian, Kecamatan Batam Kota, Kota Batam, Kepulauan Riau. Lokasi sekolah ini sangat strategis karena terletak di tengah kota dan berdekatan dengan bandara internasional Hang Nadim Batam. Sekolah ini memiliki 25 kelas dan menpunyai banyak fasilitas sekolah di antaranya ialah perpustakaan,kantin,uks,masjid dan sarana olahraga seperti lapangan bola dan lapangan basket. Sekolah ini juga menyediakan laboratorium di antaranya ialah laboratorium fisika, laboratorium kimia, laboratorium biolologi, laboratorium bahasa, laboratorium komputer, dan laboratorium audio visual.

Sekolah ini mempunyai sebuah aturan dimana para siswa harus memiliki rambut pendek, maksimal $4 \mathrm{~cm}$ di bagian atas kepala dan $2 \mathrm{~cm}$ di bagian sisi kepala. SMA Negeri Batam memiliki segudang prestasi sekolah yaitu Juara 3 OSN Kebumian pada tahun 2018, juara 1 OSN Ekonomi pada tahun 2018, juara 1 lomba OSN Kimia pada tahun 2018, juara 1 lomba karya tulis Honda pada tahun 2018. SMA Negeri 3 Batam juga mempunyai prestasi di bidang olahraga di antaranya yaitu juara 1 Futsal Pocari pada tahun 2017 dan juara 1 Hidrococo pada tahun 2018.

Berikut hasil observasi penulis,tentang lingkungan biotik dan lingkungan abiotik di sekolah SMA Negeri 3 Batam :

Tabel 1. (Gambar lingkungan biotik dan abiotik serta fasilitas di SMA Negeri 3 Batam)

\begin{tabular}{|c|c|c|c|}
\hline NO. & Lingkungan Sekolah & Gambar Lokasi & Keterangan \\
\hline 1 & Lingkungan Biotik & $\begin{array}{l}\text { Terdapat kolam } \\
\text { ikan di lingkungan } \\
\text { sekolah,yang mana } \\
\text { terdapat berbgai } \\
\text { jenis macam ikan. }\end{array}$ & \\
& & Kolam ikan di taman & \\
\hline
\end{tabular}




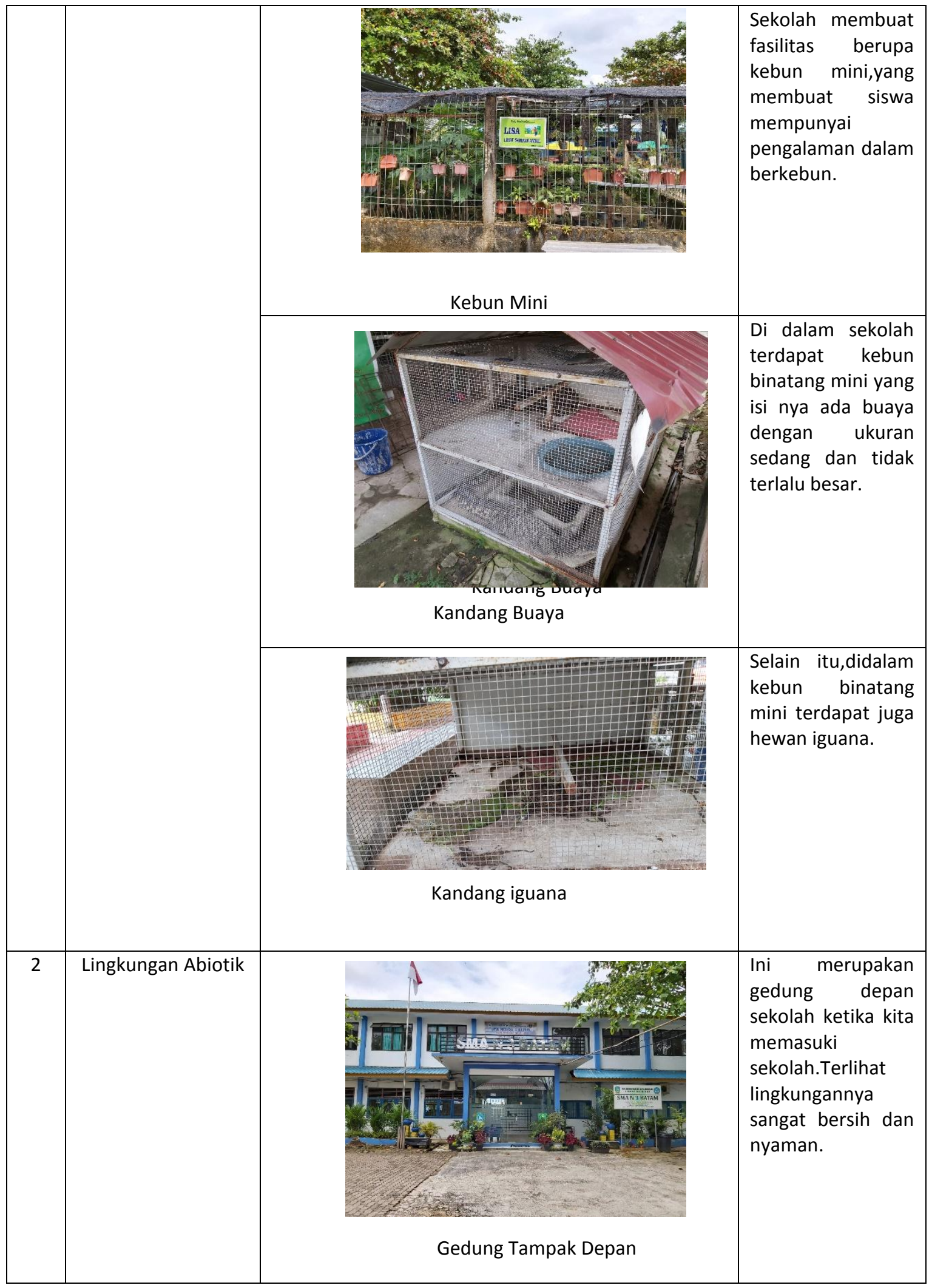




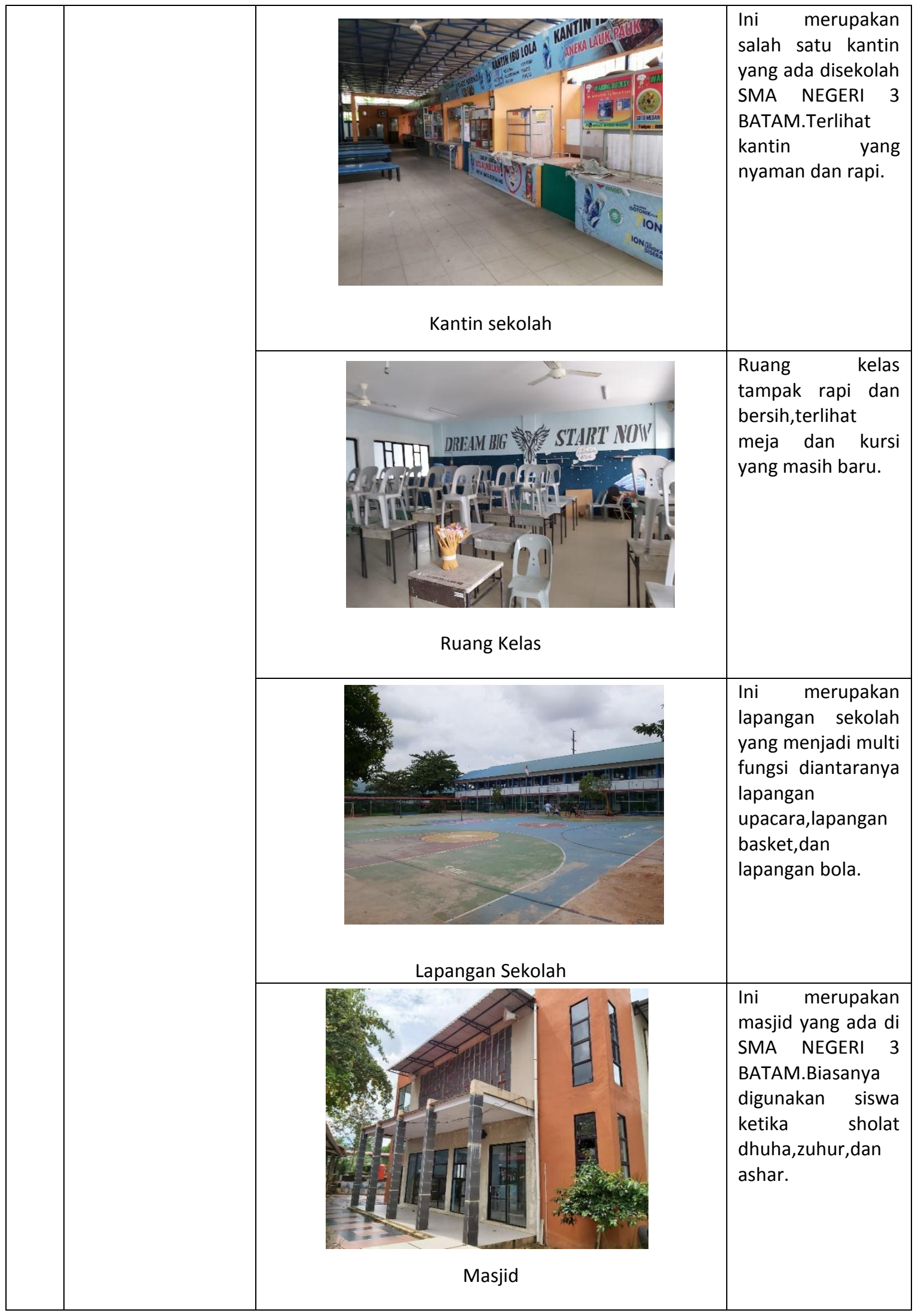




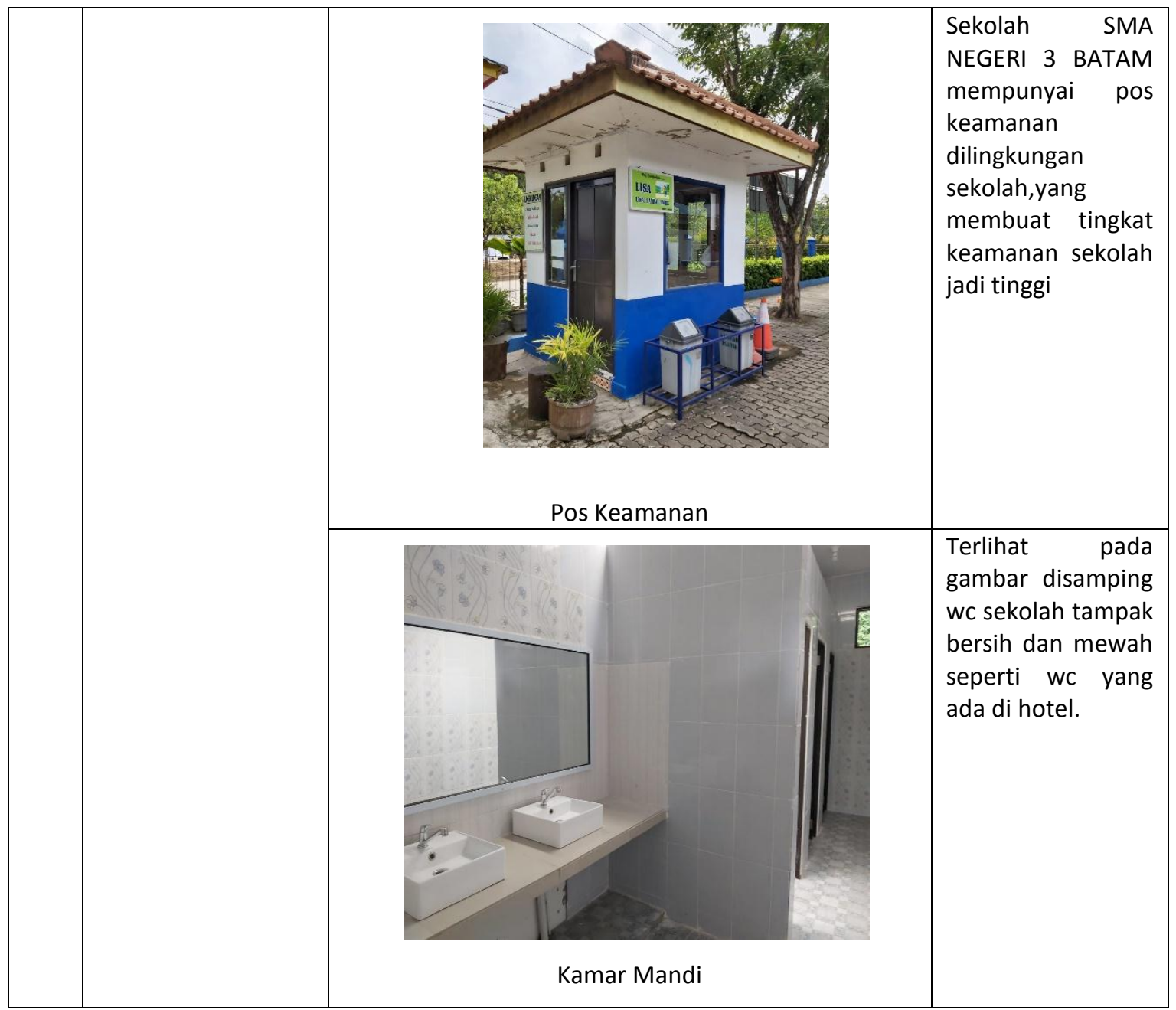

Berdasarkan tabel gambar-gambar di atas mengenai lingkungan biotik maupun lingkungan abiotik sekolah SMA Negeri 3 Batam, dapat penulis terangkan bahwa sekolah ini menerapkan sistem teori belajar behavioristik yang mana sekolah menyediakan fasilitas berupa lingkungan biotik dan abiotik. Lingkungan biotik terdiri dari kolam ikan dan kebun mini, terdapat juga beberapa hewan seperti buaya dan iguana. Adanya lingkungan biotik ini siswa diharapkan bersikap peduli antara mahluk hidup lainnya. Kemudian lingkungan abiotik yang terdiri dari gedung sekolah, kantin sekolah, ruang kelas, lapangan sekolah, kamar mandi, pos keamanan, dan masjid.

Penerapan teori belajar behavioristik dalam pembelajaran PAI dalam lingkungan abiotik adalah dengan menjaga kebersihan lingkungan sekolah dan fasilitas dari sekolah. Islam mengajarkan kita untuk hidup bersih, seperti yang telah disebutkan dalam sebuah hadits "kebersihan merupakan sebagian dari iman". Penulis berkesimpulan bahwa penerapan teori belajar behavioristik dalam pembelajaran PAI sangat tepat dilakukan di sekolah.

Proses pengumpulan data terkait dengan penerapan teori belajar behavioristik, penulis melakukan wawancara langsung dengan Ibu Becek Tang selaku guru Pendidikan Agama Islam di SMA Negeri 3 Batam. Adapun pertanyaan yang penulis ajukan kepadanya yaitu apa yang dimaksud dengan teori behavioristik menurut pandangan Ibu dan bagaimana pengaplikasiannya teori belajar behavioristik dalam pembelajaran Pendidikan Agama Islam. Jawaban yang diberikan oleh Ibu Becek Tang 
yaitu behavior berarti tingkah laku jadi teori belajar behavioristik adalah pembelajaran yang lebih menitik beratkan kepada perubahan tingkah laku. Perubahan tingkah laku ini tentunya terjadi akibat adanya interaksi antara guru dalam hal ini adalah stimulus dan juga siswa yaitu respon. Tentunya perubahan ini adalah perubahan yang lebih baik. Pertanyaan bagaimana mengetahui perubahan itu baik atau tidaknya tentu harus ada alat ukurnya, maka stimulus maupun respon dari siswa itu tentu harus dapat diamati dan diukur.

Penerapan dalam pembelajaran Pendidikan Agama Islam adalah dengan cara guru memberikan semangat belajar dan motivasi kepada siswa yang mungkin tingkah lakunya tidak bersemangat dan termotivasi untuk belajar. Guru PAI juga memberikan rangsangan agar siswa tersebut tertarik atau berminat terhadap pelajaran agama Islam. Sanksi dan reward maksudnya ialah bentuk ancaman atau seperti arahan contohnya jika siswa tidak bisa menghafal maka akan ada sanksinya. Begitu juga ketika siswa telah menghafal al-Quran karena ada beberapa ayat-ayat yang harus di hafalkan untuk materi al-Quran. Apabila siswa mampu dalam menghafal tentunya akan diberikan reward dan diberikan nilai yang bagus kepada siswa tersebut.

Pembelajaran agama Islam sebenarnya lebih banyak digunakan teori belajar behavioristik karena diketahui lebih kepada bagaimana kita bisa merubah tingkah laku peserta didik ke arah yang lebih baik. Pembelajaran Pendidikan Agama Islam memang tepat sekali ketika kita menggunakan teori belajar behavioristik, alasannya karena lebih menekankan kepada perubahan sikap. Hampir semua kompetensi menggunakan teori belajar behavioristik mulai dari aqidah yaitu menerapkan sikap yang benar pada siswa, kemudian juga dalam fikih yaitu bagaimana siswa bisa menerapkan shalat dengan benar, sebagai contoh pada tata cara shalat jenazah. Aspek-aspek yang lainnya juga memang lebih banyak kepada teori belajar behavioristik.

Berdasarkan hasil observasi dan wawancara di atas, penulis dapat menyimpulkan bahwa penerapan teori belajar behavioristik dalam pembelajaran Pendidikan Agama Islam yang dilakukan oleh Guru Pendidikan Agama Islam di SMA Negeri 3 Batam menghasilkan perubahan tingkah laku peserta didik ke arah yang lebih baik dan menunjukan sikap positif.

Berikut hasil tangkapan layar penuis dengan narasumber yaitu Ibu Becek Tang.

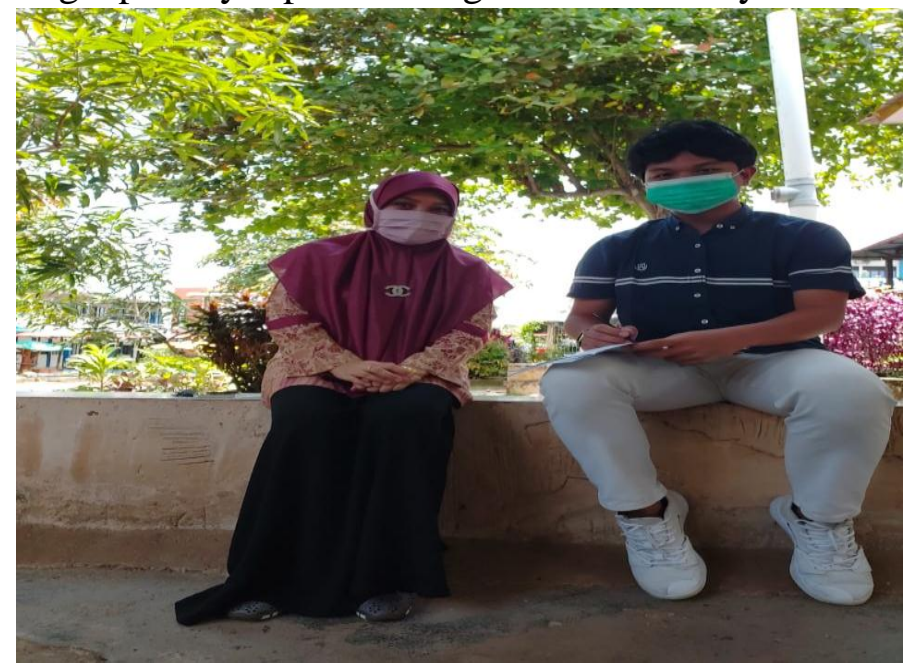

Gambar 1. Penulis bersama dengan narasumber setelah wawancara. 


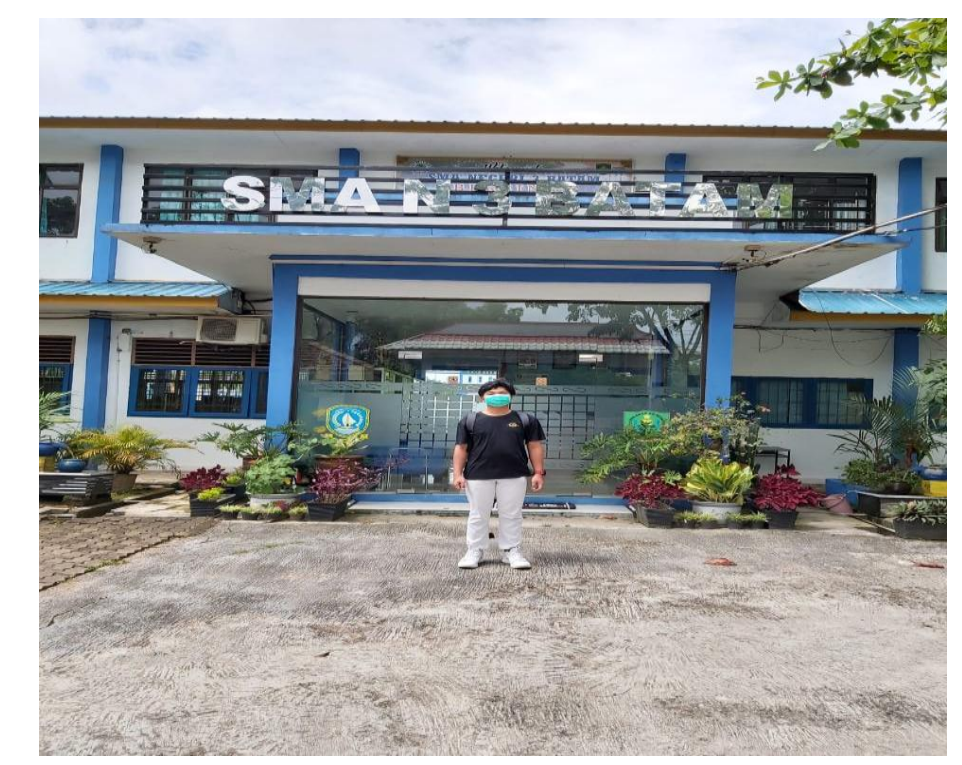

Gambar 2. Penulis ketika berada di gedung utama SMA Negeri 3 Batam

\section{Simpulan}

Teori belajar behavioristik merupakan teori yang lebih memfokuskan kepada perubahan tingkah laku terhadap peserta didik. Menurut teori belajar behavioristik, belajar merupakan hasil dari interaksi antara rangsangan dan tanggapan. Suatu individu dianggap telah belajar apabila dapat memperlihatkan perubahan tingkah lakunya.Teori ini menganggap bahwa hal yang penting dalam proses belajar adalah serapan ilmu pengetahuan yang berupa rangsangan (stimulus) dan hasil berupa tanggapan.

Kehadiran teori belajar behavioristik dalam pembelajaran Pendidikan Agama Islam di SMA Negeri 3 Batam sangat penting, karena dianggap sebagai bahan referensi yang layak untuk diterapkan dalam pembelajaran Pendidikan Agama Islam. Penulis juga berharap dengan diterapkannya teori belajar behavioristik ini mampu untuk melakukan perubahan tingkah laku peserta didik ke arah yang lebih baik sesuai dengan pembelajaran Pendidikan Agama Islam.

Pengaplikasian teori belajar behavioristik dalam pembelajaran Pendidikan Agama Islam yang dilakukan oleh guru Pendidikan Agama Islam di SMA Negeri 3 Batam menghasilkan perubahan perilaku peserta didik ke arah yang lebih baik dengan cara memberikan reward atau penghargaan, motivasi, penguatan daya ingat, toleransi, dan juga sanksi kepada peserta didik sehingga hal-hal seperti itu diharapkan dapat merubah perilaku peserta didik.

\section{Referensi}

Sugiono, (2017) Metode Penelitian Pendidikan. Jakarta: Alfabeta, hal 15.

Nana Syaodih Sukmadinata, Metode Penelitian Pendidikan (Bandung: PT. Remaja Rosdakarya, 2017), hal. 220.

Mukinan.Teori Belajar Dan Pembelajaran, Yogyakarta: P3G IKIP, 1997. 
Pratama, Yoga Anjas. Relevansi Teori Belajar Behaviorisme Dalam Proses Pembelajaran.Dalam jurnal Pendidikan Agama Islam Al-Thariqah,4.1.2019.

Putrayasa, Landasan Pembelajaran PAI : Undikhsa press, 2013.

Muhammad Fadhil Alghi Fari Majid, Suryadi. (2020). Penerapan Teori Belajar Behavioristik dalam Pembelajaran PAI, Vol.1, No. 3, April. http://jurnal.radenfatah.ac.id/index.php/pairf/article/download/4443/3033/

Zulhammi. Teori Belajar Behavioristik dan Humanistik Dalam Persfektif Islam. Darul Ilmi, Vol.3, No. 1, 2013.

Winataputra dkk. Teori Belajar Dan Pembelajaran. Jakarta : Universitas Terbuka, 2011.

Hasil Observasi di SMA Negeri 3 Batam, Tanggal 5 Oktober 2020.

Wawancara dengan Ibu Becek Tang selaku guru Pendidikan Agama Islam di SMA Negeri 3 Batam. 